\title{
Observation of the Various Growth Stages of Rice Blast Fungus (Pyricularia oryzae Cavara) by Onion Epidermal Strip Method
}

\author{
Yasuo Homma, Yutaka Arimoto, Hiroharu Takahashi* \\ and Tomomasa Misato
}

The Institute of Physical and Chemical Research, Hirosawa, Wako, Saitama 351, Japan

*Chubu Branch Sericultural Experiment Station, Agata, Matsumoto, Nagano 390, Japan

(Received January 4, 1983)

\begin{abstract}
A method was developed to test the inhibitory effects of chemicals on the growth of rice blast fungus, Pyricularia oryzae, by observing all the fungal growth stages in a single system. A drop of conidial suspension of the fungus was placed on epidermal strips of onion bulb and kept in a moist chamber at $25^{\circ} \mathrm{C}$. Conidial germination began after $3 \mathrm{hr}$ and attained to a level of $90-100 \%$ within $5 \mathrm{hr}$. Appressorial formation began immediately after conidial germination, reached $70-89 \%$ after $5 \mathrm{hr}$, and nearly $100 \% 20 \mathrm{hr}$ after the inoculation. Granulation of epidermal cells occurred after $22 \mathrm{hr}$, appressorial penetration into the epidermal cells started within $24 \mathrm{hr}$ and reached about $80-90 \% 27 \mathrm{hr}$ after inoculation. At the same time, mycelial growth was remarkable on epidermal cells. Sporulation was accelerated within 2 to 4 days after inoculation. Fifteen min after the water drops were blotted off the epidermal strips during the fungal growth, water was again dripped onto the same strips. The results showed that the fungal growth was not disturbed by this procedure, but rather promoted. We would like to propose that this method be termed the "onion epidermal strip method."
\end{abstract}

\section{INTRODUCTION}

When the effects of chemicals on fungal growth are examined, conidial germination and appressorial formation are tested usually on a slide glass, hyphal penetration by cellophane film, ${ }^{1-3)}$ mycelial development by solid media, and sporulation by solid slant media. In practice, one or more of these methods have been combined according to each purpose. However, the time course of fungal growth cannot be clarified and due to the difference in experimental systems, the results cannot be compared easily. In addition, these methods are sometimes too complicated to handle. So we pursued various methods to observe the growth of rice blast fungus ${ }^{2}$ in a single experimental system. The method of Hirata et al. applied in observing the conidial germination of Puccinia graminis on the epidermal strips of onion bulbs ${ }^{4}$ gave us a hint in regard to this experiment: namely, after dropping conidial suspension of rice blast fungus, Pyricularia oryzae on epidermal strips of onion bulbs, we could observe all the stages of rice blast fungus growth throughout its life cycle, ${ }^{5)}$ and also clarify the time course of all fungal growth stages of $P$. oryzae, ${ }^{5)}$ Diaporthe citri ${ }^{6}$ and Penicillium digitatum. ${ }^{7}$

We also tried to examine some chemical inhibition tests by this method. ${ }^{8-13)}$ As this method and the time course of each growth stage of $P$. oryzae have not been described in detail, the detailed procedure of this method and the results of $P$. oryzae obtained by this method are reported in this paper. 


\section{MATERIALS AND METHODS}

\section{Growth of Pyricularia oryzae on Epidermal} Strips of Onion Bulb

The test fungus (Pyricularia oryzae Cavara. $\mathrm{N}-2)$ was cultured on YS slant media $(0.2 \%$ yeast extract, $1.2 \%$ soluble starch, and $1.5 \%$ agar) for 8 days at $28^{\circ} \mathrm{C}$. The third or fourth epidermal strips of an onion bulb were used in the test. For observation, conidial suspension was adjusted to thirty conidia per visual field under magnification $(\times 150)$. A drop of conidial suspension $(10 \mu \mathrm{l})$ was placed on an epidermal strip of an onion bulb and kept in a moist chamber (on wet filter paper in a petri dish) at $25^{\circ} \mathrm{C}$. The procedure is illustrated in Fig. 1.

Conidial germination, appressorial formation, appressorial penetration and growth were observed 2-5.5, 3-21, and 22-27 hr after inoculation respectively. On the epidermal strips, the inoculum sporulated 2 to 6 days after inoculation. The percentage of conidial germination, appressorial formation, penetration and sporulation was counted.

\section{The Effect of Exchange of Water Phase of Conidial Suspension on the Growth of Pyri- cularia oryzae}

In order to examine the effects of chemicals on each growth stage of $P$. oryzae, water in drops of the spore suspension was blotted off with filter paper, and solutions of test chemicals were dropped on the same area on each epidermal strip of onion bulb. This procedure, of changing the water drops on the epidermal strips of onion bulb into drops of chemical solutions was usually made within $15 \mathrm{~min}$, and conducted in a little less than $3 \mathrm{hr}$ for conidial germination, $3 \mathrm{hr}$ for appressorial formation, $20 \mathrm{hr}$ for penetration and mycelial growth, and 3 days for sporulation after inoculation, respectively.

In the case of sporulation, the ideal condition for this process was when water drops were absorbed 2 days after the inoculation, otherwise, new conidia formed only around the water drops.

\section{Test Chemicals}

Dodecyl-DL-alaninate $\cdot \mathrm{HCl}(\mathrm{DA})$ and dodecyl-

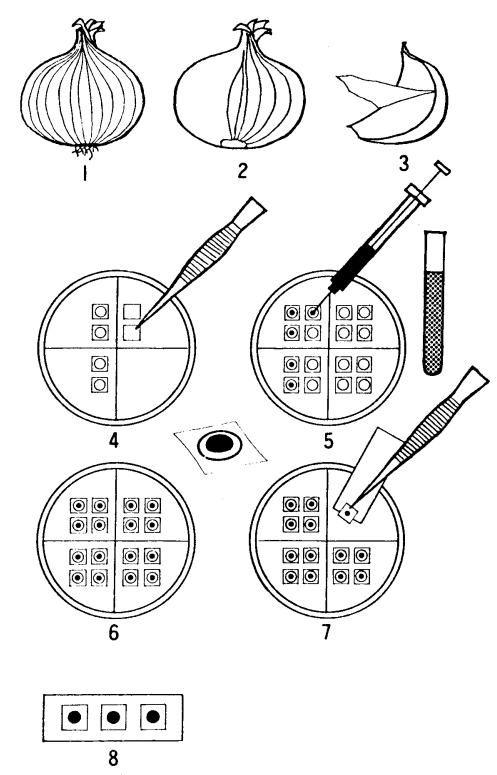

Fig. 1 The process of the onion epidermal strip method.

1: Onion bulb, 2: The ramentum of an onion bulb,

3: The epidermal strip of an onion bulb ramentum

4: The stripped epidermis is cut into $1 \mathrm{~cm} \times 1 \mathrm{~cm}$ sections, put on sterilized wet filter paper in a petri dish and then a platinum ring (about $7 \mathrm{~mm}$ in diameter) is placed on the epidermis in order to prevent it from curling, 5: A drop $(10 \mu 1)$ of conidial suspension or conidial suspension with adequate concentration of a chemical is dropped on the epidermis with a micro-syringe, 6: The petri dish is covered and kept in a humid environment at $25^{\circ} \mathrm{C}$ for adequate time, 7: After an adequate time has elapsed the inoculated epidermis is gently removed to a slide glass and then microscopically observed at various intervals, 8: The inoculated epidermises of slide glass.

DL-valinate $\mathrm{HCl}(\mathrm{DV})$ were tested at $0.1,1,5$, $10,25,75$, and $100 \mathrm{ppm}$ or $0.1,1,2.5,7.5,10$, and $100 \mathrm{ppm}$, respectively.

\section{RESULTS}

1. Growth of Pyricularia oryzae on Epidermal Strips of Onion Bulb in Various Growth Stages

\subsection{Conidial germination}

As shown in Fig. 2-1, the conidia of Pyricularia oryzae began to germinate in $3 \mathrm{hr}$ (Plate 1-1), and the percentage of conidial germination remarkably increased between 


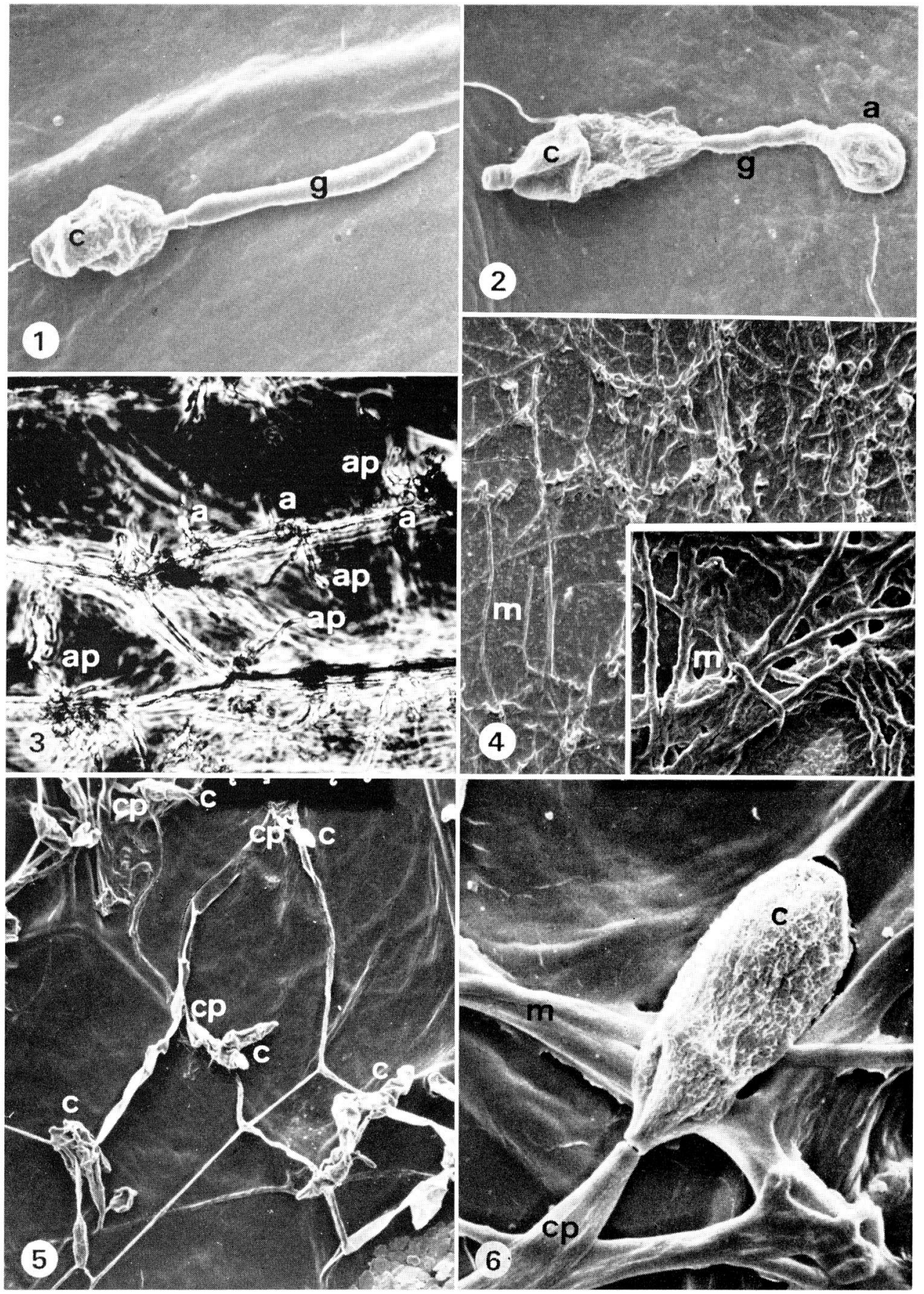

Plate 1

1: Conidial germination on epidermal strips of onion bulb, 2: Appressorial formation on epidermal strips of onion bulb, 3: Hyphal penetration into epidermal strips of onion bulb, 4: Mycelial growth on epidermal strips of onion bulb, 5: Conidial formation on epidermal strips of onion bulb, 6: Enlarged conidium.

c: conidium, g: germ tube, a: appressorium, ap: appressorial penetration, m: mycelia, cp: conidiophore 

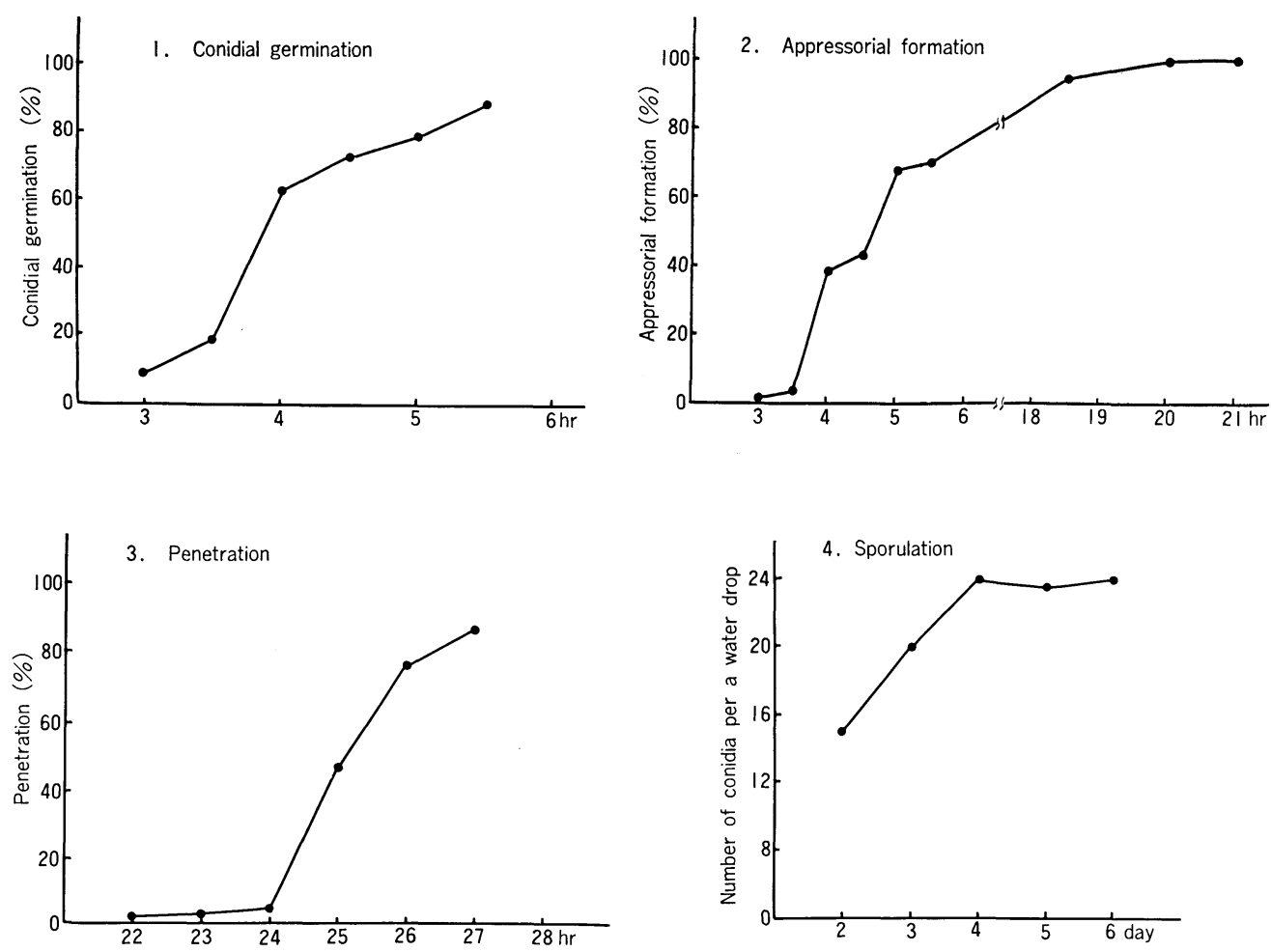

Fig. 2 The time course of each growth stage of Pyricularia oryzae on the epidermal strips of onion bulb.

3.5 and $4 \mathrm{hr}$ from the beginning of this experiment.

\subsection{Appressorial formation}

Appressorial formation started about $3.5 \mathrm{hr}$ after inoculation and rapidly increased over the initial five and half $\mathrm{hr}$, then gradually increasing, reached to nearly 100 percent $20 \mathrm{hr}$ after the suspension was dropped (Fig. 2-2). As shown in Plate 1-2, appressoria were circular in shape and a conidium formed mainly one appressorium except in some cases where, two appressoria were observed.

\subsection{Penetration}

As shown in Fig. 2-3, the penetration of $P$. oryzae into the epidermal strips of onion began at $24 \mathrm{hr}$ after dropping conidial suspension on the strips (Plate 1-3). The penetration, within $2 \mathrm{hr}$ from its beginning, rapidly developed to attain a level of about 80 percent. In addition, the penetration was evident mainly in the sutures between cells.

\subsection{Mycelial growth}

As seen in Plate 1-4 (a picture taken at $24 \mathrm{hr}$ after dropping conidial suspension), the conidia had almost germinated within $24 \mathrm{hr}$ and had become superficial mycelia on the epidermal strips of onion bulb.

\subsection{Sporulation}

As shown in Fig. 2-4, sporulation (Plate 1-5, 1-6) started within 2 days after inoculation and reached the maximum level 4 days after inoculation.

\section{The Effect of Exchange of Water Phase of Spore Suspension on the Growth of Pyricul- aria oryzae}

\subsection{Conidial germination}

Exchange of water phase from the drops on the epidermal strips of onion bulb a little earlier than $3 \mathrm{hr}$ after inoculation did not show any effect on the percentage of conidial germination as compared with the case with no exchange of water drops (non-treatment). 
Table 1 The comparison of the growth stages of $P$. oryzae in water drops with those in dried condition for $15 \mathrm{~min}$ on the epidermal strips of onion bulb.

\begin{tabular}{lcc}
\hline Growth stages & $\begin{array}{c}\text { Incubation time }(\mathrm{hr}) \\
\text { in water drops }\end{array}$ & $\begin{array}{c}\text { Per cent }(\%) \\
\text { per inoculated spores }\end{array}$ \\
\hline Conidial germination & 5 & 100 \\
& $3 \rightarrow 15$ min dry $\rightarrow \rightarrow 2$ & 100 \\
\hline Appressorial formation & 5 & 89 \\
\hline Hyphal penetration & $3 \rightarrow 15$ min dry $\rightarrow 2$ & 89 \\
\hline Sporulation & 27 & 84 \\
\hline
\end{tabular}

a) Water drops were once absorbed from the epidermal strips of onion bulb and were again poured on the same places after $15 \mathrm{~min}$.

b) The numbers indicate average figures of spores formed per a water drop on the epidermal strips of onion bulbs.

Namely, the conidial germination was $100 \%$ at $5 \mathrm{hr}$ after inoculation in each case (Table 1).

The result indicates that the treatment within about $3 \mathrm{hr}$ after inoculation did not affect conidial germination.

\subsection{Appressorial formation}

Water drops were exchanged by the same method as described above $3 \mathrm{hr}$ after inoculation. The appressorial formation was compared with the control after $3 \mathrm{hr}$. The former was higher than the latter by about 10\% (Table 1).

\subsection{Penetration}

The same procedure as described above was applied to the inoculated fungus on the onion strips at $23 \mathrm{hr}$ after inoculation. The penetration was observed under magnification. The penetration was $80 \%$ and $84 \%$, respectively, in the water-exchanged sample and control (Table 1).

The result indicates that the exchange of water in drops did not decrease the penetration percentage, but rather increased it by a few percent.

\subsection{Sporulation}

The same treatment was applied to the sporulation $48 \mathrm{hr}$ after inoculation. The number of conidia was nearly equal to that in the untreated section (Table 1). The treatment did not affect conidial germination, appressorial formation, penetration and sporulation of the fungus with the same result as in the control.

\section{Inhibition of Fungal Growth by Chemicals} 3.1 Inhibition of conidial germination

The inhibition of conidial germination by the anti-rice blast amino acid derivatives was tested. As shown in Fig. 3, 5 ppm DA did not show any effect on the conidial germination, but inhibited $75 \%$ at $10 \mathrm{ppm}$ and completely at $25 \mathrm{ppm}$. On the other hand, DV inhibited about $35 \%$ at $5 \mathrm{ppm}, 70 \%$ at $7.5 \mathrm{ppm}$, and $100 \%$ at $10 \mathrm{ppm}$, respectively.

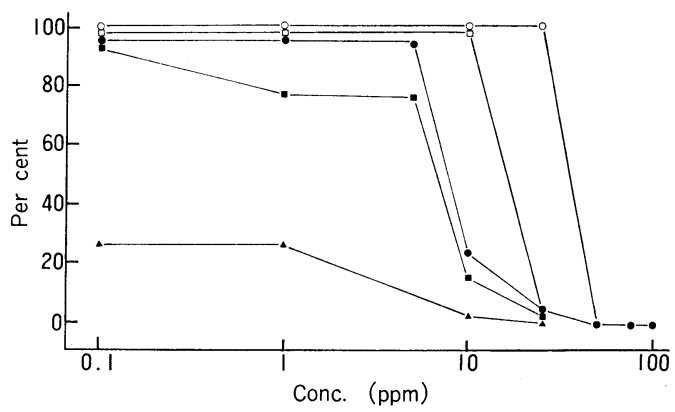

Fig. 3 Effect of dodecyl-DL-alaninate $\cdot \mathrm{HCl}$ at various growth stages of Pyricularia oryzae.

๑: Conidial germination, $\mathbf{a}:$ Appressorial formation, $\boldsymbol{\Delta}$ : Penetration, $\square$ : Hyphal growth, $\bigcirc$ : Sporulation. 
Table 2 The comparison of dodecyl-DL-alaninate $\cdot \mathrm{HCl}$ to dodecyl-DL-valinate $\cdot \mathrm{HCl}$ concerning the inhibition against growth stage of $P$. oryzae.

\begin{tabular}{lccc}
\hline \multirow{2}{*}{ Growth stages } & \multicolumn{2}{c}{ Concentration of $100 \%$ inhibition $(\mathrm{ppm})$} & \multirow{2}{*}{ DA/AV ratio } \\
\cline { 2 - 4 } & $\left.\mathrm{DA}^{\mathrm{a}}\right)$ & $\mathrm{DV}^{\mathrm{b}}$ & 2.5 \\
\hline Conidial germination & 25 & 10 & 2.5 \\
Appressorial formation & 25 & 10 & 10 \\
Appressorial penetration & 10 & 10 & 2.5 \\
Hyphal growth & 25 & 10 & 5.0 \\
Conidial formation & 50 & & \\
\hline
\end{tabular}

a) Dodecyl-DL-alaninate $\cdot \mathrm{HCl}$, b) Dodecyl-DL-valinate $\cdot \mathrm{HCl}$.

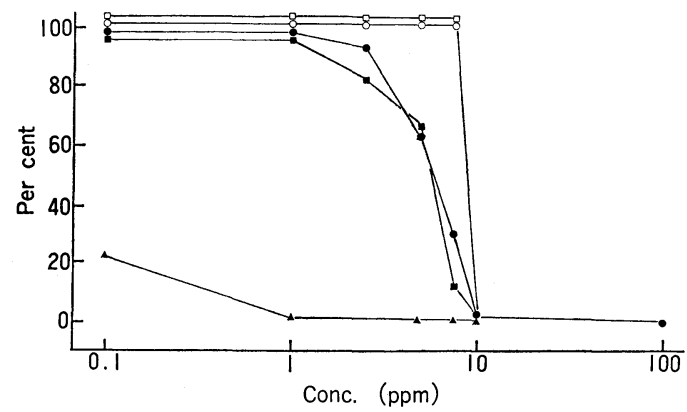

Fig. 4 Effect of dodecyl-DL-valinate. $\mathrm{HCl}$ at various growth stages of Pyricularia oryzae.

: Conidial germination, $\mathbf{\square}$ : Appressorial formation, $\Delta$ : Penetration, $\square$ : Hyphal growth, $\bigcirc$ : Sporulation.

\subsection{Inhibition of appressorial formation}

DA inhibited about $20 \%$ at $1-7.5 \mathrm{ppm}, 85 \%$ at $10 \mathrm{ppm}$, and inhibited completely at $25 \mathrm{ppm}$ or more (Fig. 3). On the other hand, DV inhibited $20 \%$ at $2.5 \mathrm{ppm}$ and completely at 10 ppm (Fig. 4).

\subsection{Inhibition of penetration}

Both DA and DV inhibited $80 \%$ of appressorial penetration at $0.1 \mathrm{ppm}$ and furthermore, both $1 \mathrm{ppm}$ of DV and $10 \mathrm{ppm}$ of DA inhibited $100 \%$ of appressorial penetration (Fig. 3, 4).

\subsection{Inhibition of mycelial growth}

It was found that $10 \mathrm{ppm}$ of DA did not inhibit the mycelial growth, but $25 \mathrm{ppm}$ of DA completely inhibited the mycelial growth (Fig. 3). DV did not inhibit the mycelial growth completely at $10 \mathrm{ppm}$ (Fig. 4).

\subsection{Inhibition of sporulation}

DA did not affect the sporulation at $25 \mathrm{ppm}$, but inhibited $100 \%$ at $50 \mathrm{ppm}$. DV did not affect the sporulation at $7.5 \mathrm{ppm}$, but inhibited $100 \%$ at $10 \mathrm{ppm}$ (Fig. 3, 4). Both the chemicals showed similar effects on the growth stages of the fungus. The order of inhibition for various growth states was penetration $>$ appressorial formation $\geqq$ conidial germination $>$ mycelial growth $\geqq$ sporulation, in inhibitory effect of both chemicals, DV was always superior to DA (Table 2).

The difference of chemical structure between the two chemicals is in valine and alanine moiety. The difference of activities based upon a little differences of the chemical structures could be analyzed by this onion epidermal strip method.

\section{DISCUSSION}

In order to clarify the inhibitory action of a chemical in various growth stages of fungi, it is desirable to compare experimental results obtained by a method. From the results of several experiments, ${ }^{2,5)}$ we found that rice blast fungus can be successfully developed throughout all growth stages of its life cycle on strips of onion bulbs. ${ }^{5}$. That is, in one of the growth stages, conidial germination was observed $3 \mathrm{hr}$ after dropping a conidial suspension. Appressorial formation immediately followed conidial germination. Granulation as observed in rice sheath cells occurred $20 \mathrm{hr}$ after inoculation, and appressorial penetration into onion epidermal strips was observed $23 \mathrm{hr}$ after inoculation.

In the previous case, 2 days after dropping a conidial suspension, sporulation was observed around the water drops of the conidial suspen- 
sion. This experiment can be conducted in a short time. Another advantage of the experimental method is that once conidial suspension is dropped, even if the drop is removed, it is possible to drip further water on exactly the same spot. In addition, after redropping water, the growth of rice blast fungus did not decrease in each growth stage. Therefore, we considered that inoculating rice blast fungus and observing the development throughout its life cycle on epidermal strips of onion bulbs are convenient for chemical inhibitory experiments.

This is one of the useful methods to know the growth stages of pathogenic fungi. ${ }^{5-7)} \mathrm{We}$ have already examined some chemical inhibitions, ${ }^{8-13)}$ and subsequently attempted to examine two compounds with consideration that the reliable results would be obtained, if we can gain similar inhibitory patterns without a great deal of differences from the test compounds with similar chemical structures.

As mentioned in the previous report, both dodecyl-DL-alaninate $\cdot \mathrm{HCl}(\mathrm{DA})$ and dodecylDL-valinate $\cdot \mathrm{HCl}(\mathrm{DV})$ have an inhibitory effect against rice blast disease. ${ }^{14)}$ These chemicals with similar structures were tested for their effect on various growth stages of rice blast fungus. Both the chemicals inhibited appressorial penetration, appressorial formation, conidial germination, hyphal growth, and sporulation in this order. Both the chemicals have similar inhibitory patterns. The difference of alanine and valine moieties in their molecules produced different strength of inhibition with the always stronger inhibition of the latter. Even the strong or weak activities depending on such a little difference in chemical structure could be analyzed by this method. After then, we could apply this method to chemical inhibitory experiments. ${ }^{8-13)}$

This method can be applied to a practical bioassay of pathogenic fungi of hydrophylic group such as rice blast fungus, citrus melanose fungus and citrus green mold fungus. Therefore we propose that it be called the "onion epidermal strip method."

\section{REFERENCES}

1) H. Oku \& H. Sumi: Ann. Phytopathol. Soc. Jpn, 34, 250 (1968) (in Japanese)

2) Y. Homma, T. Nakajima, T. Shida \& T. Misato: ibid. 39, 338 (1973)

3) F. Araki \& Y. Miyagi: J. Pesticide Sci. 2, 459 (1977)

4) K. Hirata: personal communication

5) Y. Homma, H. Takahashi, Y. Arimoto, F. Kojima \& T. Misato: Ann. Phytopathol. Soc. Jpn. 43, 70 (1977) (in Japanese)

6) K. Tomono, Y. Arimoto, Y. Homma \& T. Misato: ibid. 45, 444 (1979)

7) M. Kawai, Y. Homma, Y. Arimoto \& T. Misato: Ann. Phytopathol. Soc. Jpn. 48, 384 (1982) Abstr. (in Japanese)

8) Y. Homma, Y. Arimoto \& T. Misato: J. Pesticide Sci. 5, 611 (1980) (in Japanese)

9) K. Tomono, Y. Arimoto, Y. Homma \& T. Misato: ibid. 6, 25 (1981)

10) K. Tomono, Y. Arimoto, Y. Homma \& T. Misato: ibid. 6, 337 (1981)

11) Y. Homma, Y. Arimoto \& T. Misato: Proc. Int. Soc. Citricult. Pap. No. 643 (1981)

12) K. Tomono, M. Kawai, H. Sasaki, Y. Homma \& T. Misato: J. Pesticide Sci. 7, 329 (1982)

13) Y. Homma, Y. Arimoto \& T. Misato: IX International Congress of Plant Protection, p. 924. 1979

14) Y. Homma, T. Shida \& T. Misato: Ann. Phytopathol. Soc. Jpn. 39, 90 (1973)

\section{要 約}

\section{タマネギりん片剝離表皮検定法によるイネいも ち病菌 (Pyricularia oryzae Cavara) 生育過程 の観察}

本間保男，有本 裕，高橋広治，見里朝正 薬剂試験を目的として病原菌の生育過程を同一実験系 で観察しうる方法を検討した。 その一例としてタマネギ りん片上にイネいもち病菌の胞子懸濁液を点滴し, $25^{\circ} \mathrm{C}$ の湿室状態に保って，本菌の生育過程を観察したとこ ろ, タマネギりん片上で生活史の各生育過程を演じるこ とを知った。すなおち，分生胞子発芽は 3 時間前後から はじまり，5時間で 90 100\%に達した．付着器形成は 約 3 時間半後からはじまり，5 時間で 70 89\%，20 時 間ではほぼ 100\%に近かった。顆粒化は 22 時間後から おこり，組織内への侵入は 24 時間後から見られ，27 時 間後では約 80 ～90\% 観察された. 菌糸は 24 時間で著し く伸長した. 胞子形成は 2 日目から 4 日目にかけて增加 した. また各生育過程の途中，水滴を除き，約15分後に 再び水滴を同一場所に点滴した．この操作によって本菌 の発育は抑制されず，むしろ良好となった．薬剤による 阻害実験に本法を適用しうるので，本法を“タマネギ剝 離表皮検定法”としたい。 